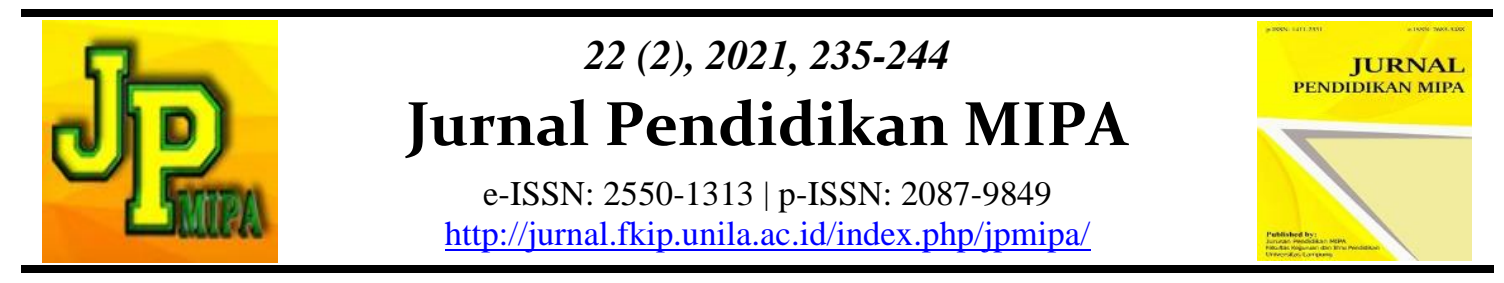

\title{
Development of Interactive Java Language Learning Module in Object Oriented Programming Subjects
}

\author{
Army Trilidia Devega ${ }^{1}$, Dedy $\operatorname{Irfan}^{2}$, Wakhinuddin², Mukhlidi Muskhir ${ }^{2}$, \\ Muhammad Ikram Jasman ${ }^{3}$ \\ ${ }^{1}$ Department of Informatics Engineering, Universitas Ibnu Sina, Indonesia \\ ${ }^{2}$ Technology and Vocational Education, Universitas Negeri Padang, Indonesia \\ ${ }^{3}$ Department of Informatics Engineering, SMKN 1 Buay Bahuga, Indonesia
}

\begin{abstract}
The purpose of this research is to develop interactive learning modules that can help students in independent learning and are valid, practical, and effective. This research was carried out using the Research and Development (R\&D) development research method with a 4D (fourD) development model. The instrument used in this study was a questionnaire used to measure validity and practicality. Meanwhile, to measure the effectiveness of using a test instrument in the form of multiple choice questions. The results showed that the interactive learning module was declared valid with a validity value of 0.88 based on the validation of three media validators and in terms of material validity it was declared valid with a value of 0.89 from two teachers who taught object oriented programming (OOP). The interactive learning module is stated to be very practical based on the responses of teachers and students. This shows that the interactive learning module is declared to be effectively used as one of the teaching materials in learning in improving student learning outcomes.
\end{abstract}

Keywords: interactive learning module, object oriented programming, research and development.

\begin{abstract}
Abstrak: Tujuan dari penelitian ini adalah untuk mengembangkan modul pembelajaran interaktif yang bisa membantu siswa dalam belajar mandiri serta valid, praktis, dan efektif. Penelitian ini dilaksanakan menggunakan metode penelitian pengembangan Research and Development $(R \& D)$ dengan model pengembangan $4 D$ (four-D). Instrumen yang digunakan pada penelitian ini berupa angket yang digunakan untuk mengukur validitas dan praktikalitas. Sedangkan untuk mengukur efektifitas menggunakan instrumen tes berupa soal pilihan ganda. Hasil penelitian menunjukan bahwa modul pembelajaran interaktif dinyatakan valid dengan nilai kevalidan 0,88 berdasarkan validasi dari tiga orang validator media dan dari segi kevalidan materi dinyatakan valid dengan nilai 0,89 dari dua orang guru yang mengajar object oriented programming (OOP). Modul pembelajaran interaktif dinyatakan sangat praktis berdasarkan respon guru dan siswa. Hal ini menunjukan bahwa, modul pembelajaran interaktif dinyatakan efektif digunakan sebagai salah satu bahan ajar dalam pembelajaran dalam meningkatkan hasil belajar siswa.
\end{abstract}

Kata kunci: modul pembelajaran interaktif, object oriented programming, penelitian dan pengembangan.

Army Trilidia Devega et al.

Email: devegaarmy@gmail.com
DOI: http://dx.doi.org/10.23960/jpmipa/v22i2.pp235-244

Received: 17 November 2021

Accepted: 19 December 2021 


\section{- INTRODUCTION}

Learning done in the classroom carried out by the teacher by using learning tools such as learning modules as a tool to deliver teaching materials to students students, so that this can help students in carry out the learning and teaching process well and effective (Yulastri, 2017; Wulansari, et, al, 2017). Support in manufacture The learning module has many using computer technology (Zaus, et, al, 2018; Devega, 2019; Sukardi, et, al, 2017). Technology computers used in making modules learning can make it easier for teachers to designing a learning process in the classroom (Pernanda, et, al, 2018; Zaus, 2018; Jalinus, 2018).

Existing learning modules adapted to core competencies (KI) and basic competencies (KD) contained in the syllabus in each subject (veza, 2020; Lapisa, et, al, 2017). KIKD is very affect the achievement of a lesson so that in making a device learning in this case the module, the teacher must also adapt it to the existing KIKD. Module made by the teacher should be in accordance with KIKD so that it is directly proportional to the result and learning objectives, but the use of modules have not been fully able to help students in learning is seen from the results of daily tests, results student skills/practice test and Middle exam almost half of the students did not achieve completeness.

Modules used to learn by students There are still some drawbacks, including: (1) the existing modules are still not attractive to be used in the learning process, because Existing modules only explain theory in writing without any simulation of the application of a learning, especially learning that is practices that require proper application included in a simulation. (2) module The learning used is still static it means that when the module is used it is difficult for students to understand the meaning of the teaching materials taught, the meaning of static here is in terms of things teaching materials only focus on one material that only in the module. (3) limitations Existing modules are difficult for outside students to access school environment. When students are outside the school environment, students find it difficult to repeating what has been learned delivered in class. Therefore, it is developed a learning module that can overcome the disadvantages described above with developing Adobe Application Interactive Module Flash Java Language on Oriented Subjects Object Programming (OOP) with a goal know the module development process learning with Adobe Flash applications, understand the use of the module that has been made as well as to test the validity, and effectiveness of the learning modules that have been created.

Developed product specifications adapted to the learning tools that consists of syllabus and lesson plans, learning materials, assignment sheets, and learning assessment sheets (Pernanda, 2018; Zaus, 2018). Modules are printed teaching materials that designed to be studied independently by learning participants. Modules are also called Modules to learn independently because in it has been Comes with instructions for selfstudy. This means that readers can carry out learning activities without the direct presence of the teacher (Riyanda, 2019; Devega, 2020; Mariyana, 2010).

The characteristics or characteristics of the appropriate module with the guidelines are 1) Self Instructional; that is able to teach students independently, 2) Self Contained; that is, all learning materials from a unit of competence or sub-competency that learned is contained in one module as a whole. The purpose of this concept is to provide opportunity for learners to learn the material complete learning, because the material is packaged into in one unified whole, 3) Standalone (stand-alone); namely the developed module does not depend on other Modules or should not used together with Module other learning. By using the module, learners are not dependent and must use Other modules to 
study and or do the tasks on the module, 4) Adaptive; module should have adaptive power high on the development of science and technology. It is said to be adaptive if the module can adapting the development of science and technology, as well as flexible use, 5) User Friendly, the module should be friendly with the user. Each instruction and information exposure who appear to be helpful and friendly with the user, including the ease of use in responding, accessing in accordance with desire (Nasional, 2008). Module components include three part (Mariyana, 2018): the opening part, core section (learning activities), closing part.

Learning by using the module makes it easier for students because there is an information map or study guide so that students are more interested and motivated to study independently. Interactive Learning Theory, Interactive learning model is often known as the child's question approach. This model is designed so that students will ask questions and then find answers to their own questions (Novita, et, al, 2021). Even if students ask questions in free activities, the questions will be too broad and often blurry so that it is less focused. Teacher need to take special steps to collect, sort, and transform these questions into activities special. Interactive learning details these steps and provides a structure for a subject that involves collecting and consideration of questions students as the center (Harlen, 1992). Stages in the model interactive learning consists of preparation prior knowledge, exploration activities, questions students, investigation, final knowledge and reflection (Yunus, 2004).

Advantages of interactive learning model including (Susanty, 2012): a. Students have more opportunities to engage his curiosity about the object to be studied, b. Train students to express their desire know through the questions that proposed by students and teachers, c. Provide play facilities for students through exploration and investigation activities, d. The teacher as a facilitator, e. Teacher as a motivator, f. Teacher As a designer of learning activities, Results learning will be more meaningful. Advantages of Learning by Using Module. Learn to use a lot of modules benefits, students can be responsible towards their own learning activities, learning with modules really appreciate the differences individually, so that students can learn according to their level of ability, then learning is getting better effective and efficient (Siagian, 2014).

Apart from that, some of the advantages from learning with the application of the module are as follows (Jerry, et, al, 1972) : a. Increase student motivation, because every time working on limited coursework clearly and according to ability, b. After the evaluation, teachers and students know correctly, on which module students have succeeded and in the part of the module that which they have not succeeded, c. Lesson materials are divided more evenly in one semester, $d$. Education is more efficient, because materials lessons are arranged according to academic level

\section{- METHOD}

The method used in this study is the Research and Development (R\&D) method. Research and development is a method research used to produce specific product, and test the effectiveness of the product it (Smith, 2003). This study uses development research with models four-D development (Suyani, 2020). This four-D model consists of of 4 main stages, namely, Define (Restrictions), Design (Design), Develop (development), and Disseminate (Dissemination). One of the reasons choosing the 4-D model is because the model with This systems approach is in accordance with the problem background of this research. As is needs analysis, see characteristics of students, and the completeness of the facilities If there is, it is hoped that research with this module can 
develop learning modules interactive application Adobe Flash Java language on Object Oriented Programming (OOP) subjects for SMK students majoring in Engineering Software (RPL). Validity and Practicality Test using questionnaire instrument in research as well as for testing effectiveness of using Pretest - Posttest Control Group Design. Data collection techniques that used for this research in the form of a test instrument This is to measure students' abilities before and after the learning process.

\section{- RESULT AND DISCUSSION}

Development carried out using the model 4-D development through four stages Module development, namely: 1. Definition stage (Define); 2. Stage of Design (Design); 3. Stage Development (Develop); 4. Deployment Stage (Disseminate).

\section{A. Defining Stage (Define)}

At this stage, there are problems that exist at the school, that is, there is still a lack of students' knowledge of learning materials given, modules given to students still in the old version no progress the latest knowledge. The teacher is still source of student knowledge, so that students only focused on teacher knowledge and notknow the latest developments.

\section{Observation}

Observations were made on subjects Object Oriented Programming (OOP) class XI majoring in Software Engineering SMK Ibnu Sina Batam is a learning process that ongoing is still teacher-centered, this is can be seen because students are passive, only rely on the teacher to get the material learning, thus causing learning takes place in a monotonous manner, this causes students become easily bored and bored.

\section{Curriculum analysis}

This curriculum analysis refers to the lesson plans, and Object Oriented course syllabus Programming (OOP). Developed material in the interactive learning module is part of the Basic and Core Competencies in the RPP and Object Oriented course syllabus Programming (OOP). KIKD developed is Java Language Programming Fundamentals\| on Lessons and syllabus for Object Oriented subjects Programming (OOP), in the KIKD There are eight main materials, namely: 1) Paradigm object-oriented programming, 2) Comparison procedural programming and programming object-oriented, 3) Primitive data types, 4) Initialization and default values, 5) Operators, 6) Decision making, 7) Loop, 8) Class \& Object.

\section{Student analysis}

In this study, the subjects were students of class XI majoring in Software Engineering at Vocational School Ibnu Sina Batam. Students in general have reached the age of 16 to 18 years. These students have the possibility and opportunity to develop their own knowledge and understanding. Therefore, achieving this stage gives students the possibility to learn independently.

\section{B. Stage of Design (Design)}

The purpose of this stage is to prepare learning device prototypes. This stage consists of of the four steps, namely: 
1. Development of benchmark reference tests

Based on the objectives that have been formulated, then the item development is carried out assessments to measure students' abilities such as estimated in the destination. This test is structured based on the results of a special formulation. This test is a tool to measure the occurrence of behavioral changes in students after teaching and learning activities.

\section{Application Selection}

Applications used in development This Java language interactive learning module is Adobe Flash CS 6 software. The lessons to be learned done is learning with using interactive learning modules where students can hone their skills and his dexterity by using the device which has been provided. Adobe Flash is selected for making the features contained in the module interactive because this software is very supportive for the creation of interactive modules, creation of buttons and can integrate text, images, and background.

\section{Designing the Prototype}

This interactive learning module is designed which must be made before validation and field research. At this stage it is done preparation of the framework in the learning module interactive in the form of a module display design that includes the opening page, the home page is the main menu of the module, material page, evaluation page containing questions to test student's ability to the material presented in the module. The result of the display design is learning module interface design

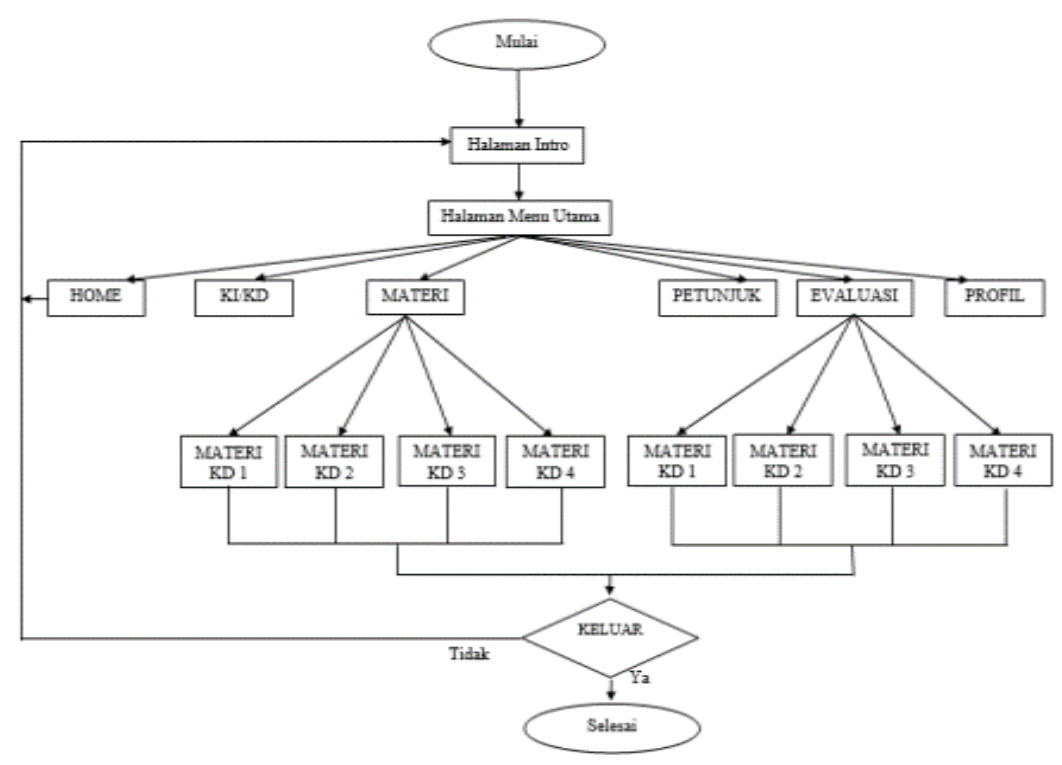

Figure 1. product design flow 


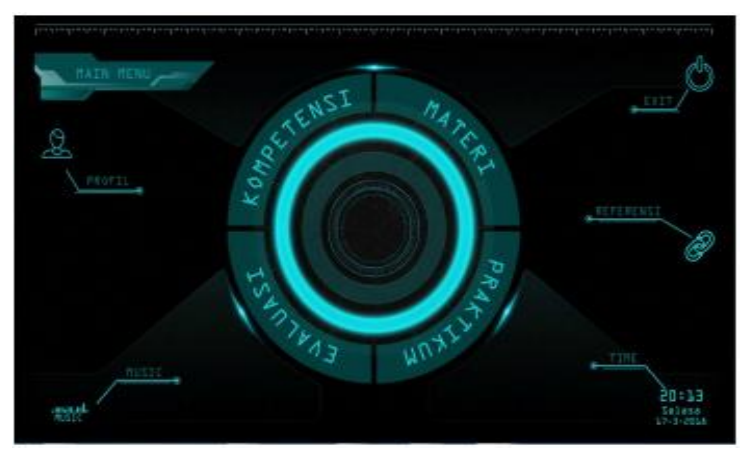

Figure 2. Main Menu Page Display

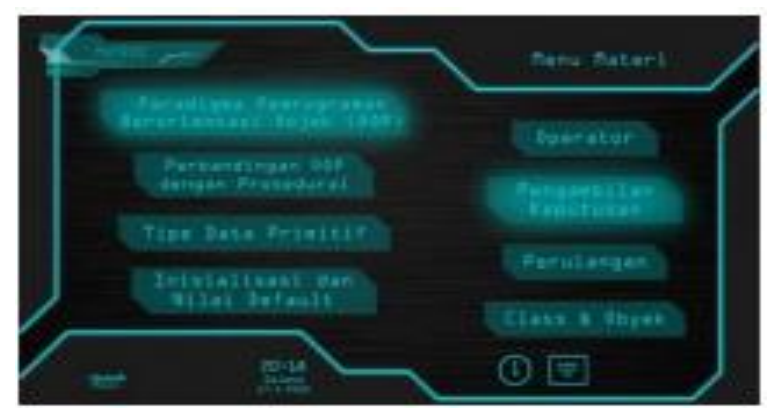

Figure 3. Material Page View

\section{Development Stage}

\section{Validation Test}

The purpose of expert validation is to get input, criticism, and suggestions for improvement for the perfection of the developed Module. Validation test data obtained through the instrument validation filled by several validators who is a learning module expert. Validator consists of 5 people, namely three people for the validator module and two people for the material validator. Expert validation Module focused on display or presentation seen from the point of view of the Module. Validation by experts The module aims to make the product Adobe Flash-based interactive learning module CS6 developed into a product that quality in terms of programming and appearance.

Data from the validator was obtained from a questionnaire that has been given an assessment by three validators. The first, second and third validators provide the average value of 0.88 , so it can be said that the design of this interactive learning module valid. Based on suggestions and assessments from validators both in terms of content and design, revisions are made to this interactive learning module, so that developed interactive learning module worth testing.

Table 1. module validation assessment results

\begin{tabular}{cccc}
\hline No & Assessment Aspect & Average & Category \\
\hline 1 & Audio & & \\
\hline 2 & Taxt & 0,88 & Valid \\
\hline 3 & Video & & \\
\hline 4 & Serving Messages & & \\
\hline
\end{tabular}


From the results of material validation by experts, it can be it is known that the interactive learning module that has been developed to reach a valid category with the average score of validity is 0.89 . Rating result This is also in line with the results of research that previously conducted by Nuryadin Eko Raharjo (2011) which shows the percentage of yield achieving an average score of $85.34 \%$ in the category is very valid, so that from the point of view of the correctness of the accuracy of the material in the Module, Modul interactive learning is feasible for tested in the field.

\section{Practicality of Interactive Learning Module}

Interactive learning module practicality data taken through a test conducted at SMK Ibnu Sina Batam which aims to see the implementation learning by using modules this interactive learning. To see practicality, interactive learning module that has been validly used in the learning process by the teacher. At the end of the lesson, teachers and students asked to fill out a practicality questionnaire from the module interactive learning that has been used.

\section{Assessment of the practicality of the module}

This interactive learning was obtained from a questionnaire filled in by practicing teachers and the results of the assessment obtained from the teacher's response questionnaire to practicality of this interactive learning module is $93.33 \%$ in the category of practicality very practical. In addition to assessments from teachers/practitioners, the practicality of this interactive learning module too assessed based on student responses and results It is known that in the student response questionnaire, it is obtained value of $87.50 \%$ so it can be concluded that the interactive learning module that developed is practical with categories practicality is very practical. The results of this trial are in line with the results of previous research conducted by Raharjo (2011) which shows achievement a percentage of $85.34 \%$ in the very category practice and research Machfudhoh (2016) which shows the results of student responses with achievement percentage of $90.25 \%$ in very practical category.

\section{Effectiveness of Interactive Learning Module}

The effectiveness of interactive learning modules on This research is seen to be used to facilitate students in understanding the learning material, as well as the effectiveness of the interactive learning modules that used can be seen from the results of cognitive learning student. Learning outcomes are abilities that students have after they go through the process learning experience. Learning outcomes are obtained from pretest and posttest 28 students were given in the form of an objective test as many as 25 items. Based on the data obtained from the module test results this interactive learning, researchers can explain that there is a significant difference significant on the results of the pre-test and post-test classes. Based on table 4.10 shows that $80.25 \%$ have reached the passing grade.

The results of this study are relevant to the research conducted by Deno (2016) which obtained results test the effectiveness of student learning outcomes of $78.2 \%$ in the good category obtained from the assessment students' cognitive learning outcomes from pre-test and post-test, it is explained that students who have not completed (passing grade <75) are 7 students $(21.8 \%)$ and who have reached the passing grade as many as 25 students $(78.2 \%)$ and the classical completeness is categorized good, so it can be concluded that the Modul interactive learning is effective. Nuryadin Eko Raharjo (2011) 
with the percentage of effectiveness of $87.18 \%$, students can score above the passing grade, while $12.82 \%$ have not reached the passing grade. So that seen from the cognitive learning outcomes of students who follow the lesson by using the module interactive learning, shows that the module interactive learning developed by researchers effective to improve student learning outcomes.

\section{Dissemination}

Dissemination or dissemination stage done by implementing the module This interactive learning is in the learning process teach OOP subjects, especially in basic competence Understand the concept of OOP which distributed to other classes, namely class XI RPL Vocational School Ibnu Sina Batam. Deployment can also be done through a process of transmission to practitioners related learning in a particular forum. Based on the explanation above, it can be concluded that this Interactive Learning Module is a one of the test modules that are valid, practical, and effective for use in the learning process. This is in accordance with the opinion of Thiagarajan (1974) Dissemination stage is done to promote product development to be accepted by users, either an individual, a group or a system\|, at this stage it is carried out offline with the name Java language interactive learning module application in object-oriented programming subjects.

\section{- CONCLUSION}

Based on the results of data analysis and discussion research that has been carried out by researchers, can concluded that this development produce a learning module interactive valid, practical and effective, on the eye class XI OOP lessons, majoring in RPL, this is roven because of the learning module This interactive experience has been tested for validity, practicality and effectiveness to validators, teachers and students. Module this developed interactive learning based on competency standards, and basic competencies of OOP subjects.

\section{- REFERENCES}

Devega, A. T. (2020). Pengembangan Media Pembelajaran Berbasis Multimedia Linier Pada Mata Kuliah Hardware Dasar [Development of Learning Media Based on Linear Multimedia in Basic Hardware Courses]. Engineering and Technology International Journal, 2(01), 11-20.

Devega, A. T., \& Suri, G. P. (2019). Pengembangan Media Pembelajaran Interaktif untuk Siswa SMK [Development of Interactive Learning Media for Vocational High School Students]. Engineering and Technology International Journal, 1(01), 1118.

Harlen, W., Gipps, C., Broadfoot, P., \& Nuttall, D. (1992). Assessment and the improvement of education. The curriculum journal, 3(3), 215-230.

Jalinus, N. (2018). Effectivity of The Cooperative-Project Based Learning (CPjBL) in Enhancing HOTS of Vocational Education Students.

Jerry, R. W., Crittenden, W., \& William, B. (1972). Learning Modules: A concept for extension educators. Journal of extension.

Lapisa, R., Basri, I. Y., Arif, A., \& Saputra, H. D. (2017). Peningkatan Kompetensi Siswa Melalui Pelatihan Auto CAD [Improving Student Competence Through Auto CAD Training]. INVOTEK: Jurnal Inovasi Vokasional dan Teknologi, 17(2), 119-126. 
Mariyana, H., \& Mustika, I. W. (2010). Pengembangan Modul Pembelajaran Tari Piring Dua Belas di SMA Bandar Lampung [Development of the Plate Twelve Dance Learning Module at SMA Bandar Lampung],\|. FKIP Unila, (1).

Nasional, D. P. (2008). Departemen Pendidikan Nasional. Kamus Besar Bahasa Indonesia. Jakarta: Pusat Bahasa.

Novita, A., Saragih, S., Lubis, E., Gemda, A. R., Fitria, F., Susanti, R., ... \& Mariana, M. (2021). Provide Student Knowledge About How Response On Growth Of Vetiver Seeds (Vetiveria zizanioides) In Saline Soil To Ascorbic Acid on Field Practice Learning of Plant Physiology. Jurnal Serambi Ilmu, 22(1), 126-138.

Pernanda, D., Zaus, M. A., Wulansari, R., \& Islami, S. (2018, April). Effectiveness of instructional media based on interactive cd learning on basic network at vocational high school: improving student cognitive ability. In International Conferences on Educational, Social Sciences and Technology (pp. 443-447). Fakultas Ilmu Pendidikan UNP.

Pernanda, D., Zaus, M. A., Wulansari, R., \& Islami, S. (2018, April). Effectiveness of instructional media based on interactive cd learning on basic network at vocational high school: improving student cognitive ability. In International Conferences on Educational, Social Sciences and Technology (pp. 443-447). Fakultas Ilmu Pendidikan UNP.

Riyanda, A. R., \& Suana, W. (2019). Pengembangan Modul Pembelajaran Pemrograman Dasar Berbasis Adobe Flash CS6 Bagi Siswa Kelas XI RPL [Development of Basic Programming Learning Module Based on Adobe Flash CS6 for Class XI RPL students]. Jurnal Pendidikan Teknologi Informasi dan Vokasional, 1(2).

Siagian, S. (2014). Development of basic electronic instructional module and trainer. European Journal of Computer Science and information technology, 2(3), $36-46$.

Smith, P. A., \& O’Neil, J. (2003). A review of action learning literature 1994-2000: Part 1-bibliography and comments. Journal of Workplace learning.

Sukardi, S., Puyada, D., Wulansari, R. E., \& Yanto, D. T. P. (2017). The validity of interactive instructional media on electrical circuits at vocational high school and technology. 2nd INCOTEPD, 2017, 21-22.

Susanty, P. E., \& Kusumastuti, E. (2012). Model Pembelajaran Interaktif Kelompok pada Mata Pelajaran Seni Tari [Group Interactive Learning Model in Dance Subject]. Jurnal Seni Tari, 1(1).

Suyani, K., Astawan, I. G., \& Renda, N. T. (2020). Pengembangan Perangkat Pembelajaran Model Discovery learning Berbasis Lingkungan Pada Mata Pelajaran IPA Siswa Kelas IV Sekolah Dasar [Development of Environmental Based Discovery Learning Model Learning Devices in Science Subjects for Class IV Elementary School Students]. Jurnal Ilmiah Pendidikan Profesi Guru, 3(3), 512519.

Veza, O., Devega, A. T., Mawaddah, M. A., \& Arifin, N. Y. (2020). Desain dan Analisis Implementasi Motion Graphic Program Publikasi Sebagai Media Promosi Batam TV [Design and Analysis of the Implementation of Motion Graphic Publication Programs as Promotional Media for Batam TV]. Jurnal Teknik Ibnu Sina (JTIBSI), 5(02), 46-56.

Wulansari, R. E., Puyada, D., Wijaya, I., \& Rukun, K. (2017). Effectiveness Of Instructional Media Based Game On Mathematics At Vocational High School. Int. J. Res. Sci. Manag, 4(12), 125-128. 
Yulastri, A., \& Hidayat, H. (2017). Developing an Entrepreneurship Module by Using Product-Based Learning Approach in Vocational Education. International Journal of Environmental and Science Education, 12(5), 1097-1109.

Yunus, H. M., Ismail, Z., \& Raper, G. (2004). Malaysian Primary Teachers' Classroom Practice of Teaching and Learning Science. Journal of Science and Mathematics Education in Southeast Asia, 27(1), 166-203.

Zaus, M. A., \& Krismadinata, K. (2018). Suatu Kajian Literatur Masalah-Masalah yang Dihadapi dalam Mata Kuliah Jaringan Komputer [A Literature Study of the Problems Faced in Computer Networking Courses]. INVOTEK: Jurnal Inovasi Vokasional Dan Teknologi, 18(2), 1-8.

Zaus, M. A., Wulansari, R. E., Islami, S., \& Pernanda, D. (2018). Perancangan Media Pembelajaran Listrik Statis dan Dinamis Berbasis Android [Design of Static and Dynamic Electricity Learning Media Based on Android]. INTECOMS: Journal of Information Technology and Computer Science, 1(1), 1-7. 